Turkish Journal of Internal Medicine PASE
$\frac{h t t p: / / w w w . t j i m .0 r g}{\text { ISSN: } 2687-4245}$

\title{
Chronic kidney disease presenting with bilateral spontaneous femoral neck fracture: A case report
}

Mehmet Usta ${ }^{1}$, Alparslan Ersoy², Canan Ersoy³, Gültekin Göksel ${ }^{1}$

${ }^{1}$ Nephrology Clinic, Bursa City Hospital, Bursa, Turkey

${ }^{2}$ Division of Nephrology, Department of Internal Medicine, Uludag University Faculty of Medicine, Bursa, Turkey

${ }^{3}$ Division of Endocrinology \& Metabolism, Department of Internal Medicine, Uludag University Faculty of Medicine, Bursa, Turkey

\begin{abstract}
Bone and mineral metabolism disorders are common in patients with chronic kidney disease (CKD). These patients are susceptible to fractures. Bilateral femoral neck fracture secondary to renal osteodystrophy is a rare complication. We report a case of CKD with bilateral spontaneous femoral neck fracture associated with secondary hyperparathyroidism and osteoporosis.
\end{abstract}

Turk J Int Med 2019;1(1):30-33

Keywords: Bone and mineral disorders, chronic kidney disease, fracture, osteoporosis, secondary hyperparathyroidism.

\section{Introduction}

Progression of chronic kidney disease (CKD) leads to various bone diseases and mineral metabolism disorders due to changes in calcium $(\mathrm{Ca})$, phosphorus $(\mathrm{P})$, parathyroid hormone $(\mathrm{PTH})$ and vitamin $\mathrm{D}$ metabolism in these patients. Chronic kidney disease-mineral and bone disorder (CKD-MBD) may present with different clinical manifestations depending on existing metabolic abnormality and characteristic bone disease. Patients with end-stage renal disease (ESRD) are at increased risk for bone loss and are susceptible to fractures, especially hip fractures. ${ }^{1,2}$ Osteoporosis is a skeletal disorder characterized by compromised bone strength predisposing to an increased risk of fracture, and CKD-MBD is one of the possible causes of osteoporosis. ${ }^{2}$ Here we report a patient who was diagnosed with new CKD and bilateral femoral neck fracture.

\section{Case Report}

A 22-year-old male patient was admitted to another hospital with complaints of weakness and difficulty in walking and was referred to our hospital because of high serum urea and creatinine levels. His previous medical history was unremarkable, and his blood pressure was 110/60 $\mathrm{mmHg}$ and pulse 72 beats/min. He had bilateral diffuse hip sensitivity and limitation of motion. His laboratory tests revealed that serum glucose $94 \mathrm{mg} / \mathrm{dL}$, urea $87 \mathrm{mg} / \mathrm{dL}$, creatinine $6.3 \mathrm{mg} / \mathrm{dL}$, 
uric acid $10.7 \mathrm{mg} / \mathrm{dL}$, albumin $4.8 \mathrm{~g} / \mathrm{dL}$, sodium $131 \mathrm{mEq} / \mathrm{dL}$, potassium $3.9 \mathrm{mEq} / \mathrm{dL}, \mathrm{Ca} 6.7 \mathrm{mg} /$ $\mathrm{dL}, \mathrm{P} 3.5 \mathrm{mg} / \mathrm{dL}$, AST $54 \mathrm{IU} \backslash \mathrm{L}$, ALT $17 \mathrm{IU} \backslash \mathrm{L}$, serum alkaline phosphatase (ALP) 573 IU $\backslash L$, hemoglobin $9.29 \mathrm{~g} / \mathrm{dL}, \mathrm{CRP} 30.4 \mathrm{mg} / \mathrm{dL}, 25 \mathrm{OH}$ vitamin D $4 \mathrm{ng} / \mathrm{mL}$, intact PTH $559 \mathrm{pg} / \mathrm{mL}$ and ferritin $238 \mathrm{ng} / \mathrm{mL}$. Hepatitis B and C tests were negative. Renal ultrasonography showed reduced renal size and grade III echogenicity and was consistent with CKD. eGFR was $4 \mathrm{~mL} / \mathrm{min} / 1.73$ $\mathrm{m}^{2}$. The patient' findings were consistent with ESRD. Direct anterioposterior pelvic radiograph revealed a bilateral femoral head fracture (Figure 1). In his dual-energy $x$-ray absorptiometry (DEXA) scan, the $\mathrm{T}$ score was -2.8 and the $\mathrm{Z}$ score was -1.6 . In $\mathrm{MR}$ imaging of the left and right hip joints, there was complete fracture in the both femoral necks. It was displaced about 3-4 cm from the level of fracture on both sides towards the superior of the trochanteric section of the femur. It was thought that fractures might be related to CKD-MBD in the patient who had no history of trauma or seizure. He underwent total hip replacement operation for fractures in both femoral neck (Figure 1). Dialysis treatment, calcium and vitamin $\mathrm{D}$ supplements were started.

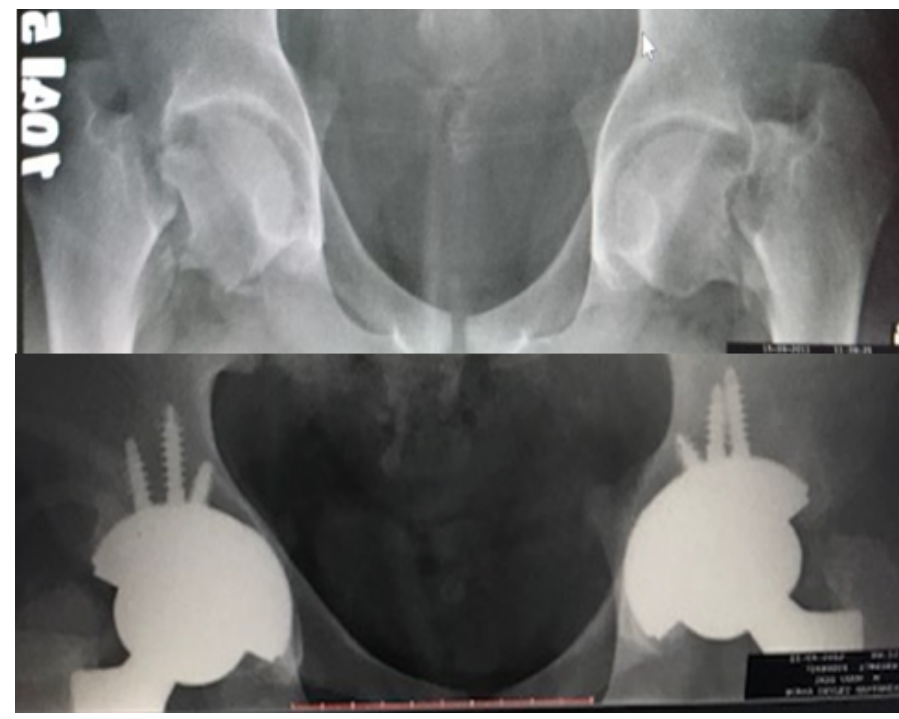

Figure 1. Pre- and post-operative radiographs of the patient showing bilateral femoral neck fractures

\section{Discussion}

The risk of fracture in hemodialysis, peritoneal dialysis and kidney transplant patients is higher when compared with the general population. ${ }^{3}$ The recent observational study showed that the fracture risk of dialysis patients was $16 \%$ higher than that of pre-dialysis CKD patients. ${ }^{4}$ In another study including 68,764 individuals with confirmed CKD with a median follow-up of 2.7years, 9,219 fractures occurred, of which 3,105 were hip fractures. A more severe CKD stage was associated with a higher risk of fractures, particularly hip fractures: compared with CKD Stage $3 a$, the adjusted HR was 1.10, 1.32 and 2.47 for CKD Stage 3b, 4 and 5, respectively. ${ }^{5}$

Risk factors for fracture in CKD patients are similar to those in the general population, such as low body weight, menopause, a history of personal and familial osteoporosis, chronic inflammatory diseases and corticosteroid usage. ${ }^{6}$ Some bone histology types such as osteomalacia, high turnover bone disease or adynamic bone disease in CKD-MBD is associated with the elevated rates of bone fracture. ${ }^{7}$ Spontaneous bilateral femoral neck fracture in a renal disease patient is a rare complication. A retrospective analysis of etiological factors in 26 pathological fractures of the femoral neck of 19 chronic hemodialysis patients with 11 (range 2 to 21) years of mean duration of dialysis was found the presence of beta-2-microglobulin amyloidosis, aluminic osteomalacy, osteoporosis, and cortisonic necrosis and porosis. ${ }^{8}$ Certain risk factors including high PTH levels and the use of narcotics and psychoactive medications may increase the likelihood of fracture. ${ }^{9}$ Secondary hyperparathyroidism may cause lead bilateral spontaneous simultaneous rupture of the Achilles tendon and pathological fracture of right femur neck in patients after the long-term hemodialysis without predisposing factors such as previous use of corticosteroids or fluoroquinolones..$^{10}$ Femoral neck fractures in elderly dialysis patients are associated with advanced renal osteodystrophy and multiple medical problems such as confusion caused by narcotics and analgesics, pneumonia, hepatic coma, decubitus ulcers, severe depression and severe hypoalbuminemia. ${ }^{11}$ There was no history of injury, trauma, fall, seizure, steroid medication, fluoride treatment, smoking and alcohol abuse in our case. Several cases of bilateral femoral neck fractures have been reported in patients with CKD in the literature. ${ }^{11-23}$ Hypocalcaemic convulsions or muscle cramps can also cause fractures in patients with CKD. ${ }^{11,14-16}$

Bone mineral density (BMD) was low in our case with secondary hyperparathyroidism. 
BMD was also significantly lower in patients with secondary hyperparathyroidism than in those with adynamic bone disease. A prospective study including 62 hemodialysis patients that $11 \%$ of all had a positive fracture history showed that osteopenia was frequentin patients on hemodialysis, especially those with biochemical and histological findings of secondary hyperparathyroidism. ${ }^{24}$ A meta-analysis investigating the relationship between $B M D$ values and fractures in patients with stage $5 \mathrm{CKD}$ shows that $\mathrm{BMD}$ is lower in patients with fractures. ${ }^{25}$ A total of 374 patients with CKD G3a-G5 was followed by DEXA for a total of 5 years, and measured BMD. $14.3 \%$ of patients with G3a and G3b, $15.7 \%$ of of patients with G4, and $19.7 \%$ of of patients with G5 experienced a clinical fracture during the study period. The multivariate analysis showed that each decline of 1.0 SD in total hip BMD T-Score was associated with a significant increase in the risk of fracture (OR = 1.46). ${ }^{26}$ Furthermore, both genders with impaired kidney function are at increased risk of bone loss, even with minimal reduction in kidney function. ${ }^{27}$ PTH can stimulate bone resorption which renders the bone susceptible to fractures. Ayurvedic medications also may accelerate osteoporosis of the proximal femur, and lead to bilateral femur neck fractures. A 41-year-old male who was diagnosed with CKD for 6 months and started taking Ayurvedic medications after the diagnosis had a trivial trauma 2 months before. As our case, the patient was admitted for inability to walk, and was diagnosed bilateral femur neck fracture. ${ }^{28}$

Hip and long-bone fractures are associated with an increased risk of all-cause mortality, major cardiovascular and infectious events in the dialysis population. ${ }^{29,30}$ In our patient who was diagnosed as end-stage renal disease, high $\mathrm{PTH}$, low vitamin $\mathrm{D}$, low calcium and high ALP levels were consistent with high-turnover bone disease. Serum ALP is a marker of high-turnover bone disease and is associated with coronary artery calcification and death risk in hemodialysis patients. A relationship between high serum ALP and worse BMD has been reported in dialysis patients. ${ }^{31}$ A large cohort study revealed that higher serum ALP levels were independently associated not only with mortality but also with the incidence of hip fracture in Japanese hemodialysis patients. ${ }^{32}$

As a result, bilateral femoral neck fractures without risk factors such as trauma, convulsion and steroid medication are rare in a young patient with CKD. Since the presence of secondary hyperparathyroidism and osteoporosis increases the risk of fracture in patients with CKD even in the early stages, physicians should consider the possibility of developing this complication in the follow-up of such patients.

\section{Conflict of interest}

The authors declared that there are no potential conflicts of interest with respect to the research, authorship, and/or publication of this article.

\section{References}

1. Alem AM, Sherrard DJ, Gillen DL, Weiss NS, Beresford SA, Heckbert SR, Wong C, Stehman-Breen C. Increased risk of hip fracture among patients with end-stage renal disease. Kidney Int. 2000 Jul;58(1):396-9.

2. Kazama JJ. Chronic kidney disease and fragility fracture. Clin Exp Nephrol. 2017 Mar;21(Suppl 1):4652. doi: 10.1007/s10157-016-1368-3.

3. Sidibé A, Auguste D, Desbiens LC, Fortier C, Wang YP, Jean S, Moore L, Mac-Way F. Fracture Risk in Dialysis and Kidney Transplanted Patients: A Systematic Review. JBMR Plus. 2018 Jul 5;3(1):45-55. doi: 10.1002/ jbm4.10067.

4. Kwon YE, Choi HY, Kim S, Ryu DR, Oh HJ; ESRD Registry Committee of the Korean Society of Nephrology. Fracture risk in chronic kidney disease: A Korean population-based cohort study. Kidney Res Clin Pract. 2019 Jun 30;38(2):220-8. doi: 10.23876/j. krcp.18.0099.

5. Runesson B, Trevisan M, Iseri K, Qureshi AR, Lindholm B, Barany P, Elinder CG, Carrero JJ. Fractures and their sequelae in non-dialysis-dependent chronic kidney disease: the Stockholm CREAtinine measurements project. Nephrol Dial Transplant. 2019 Jul 30. pii: gfz142. doi: 10.1093/ndt/gfz142.

6. Torres PAU, Cohen-Solal M. Evaluation of fracture risk in chronic kidney disease. J Nephrol. 2017 Oct;30(5):653-61. doi: 10.1007/s40620-017-0398-6.

7. Tentori F, McCullough K, Kilpatrick RD, Bradbury BD, Robinson BM, Kerr PG, Pisoni RL. High rates of death and hospitalization follow bone fracture among hemodialysis patients. Kidney Int. 2014 Jan;85(1):16673. doi: 10.1038/ki.2013.279.

8. Hardy P, Benoit J, Donneaud B, Jehanno P, LortatJacob A. [Pathological fractures of the femoral neck in hemodialyzed patients. Apropos of 26 cases]. Rev Chir Orthop Reparatrice Appar Mot. 1994;80(8):702-10.

9. Jadoul M, Albert JM, Akiba T, Akizawa T, Arab L, Bragg-Gresham JL, Mason N, Prutz KG, Young EW, Pisoni RL. Incidence and risk factors for hip or other bone fractures among hemodialysis patients in the 
Dialysis Outcomes and Practice Patterns Study. Kidney Int. 2006 Oct;70(7):1358-66.

10. Ureten K, Oztürk MA, Ozbek M, Unverdi S. Spontaneous and simultaneous rupture of both Achilles tendons and pathological fracture of the femur neck in a patient receiving long-term hemodialysis. Int Urol Nephrol. 2008;40(4):1103-6. doi: 10.1007/s11255-0089421-0.

11. Schaab PC, Murphy G, Tzamaloukas AH, Hays MB, Merlin TL, Eisenberg B, Avasthi PS, Worrell RV. Femoral neck fractures in patients receiving long-term dialysis. Clin Orthop Relat Res. 1990 Nov;(260):224-31.

12. Zingraff J, Drueke T, Roux JP, Rondon-Nucete M, Man NK, Jungers P. Bilateral fracture of the femoral neck complicating uremic bone disease prior to chronic hemodialysis. Clin Nephrol. 1974;2(2):73-5.

13. Gerster JC, Charhon SA, Jaeger P, Boivin G, Briancon D, Rostan A, Baud CA, Meunier PJ. Bilateral fractures of femoral neck in patients with moderate renal failure receiving fluoride for spinal osteoporosis. Br Med J (Clin Res Ed). 1983 Sep 10;287(6394):723-5.

14. Undar L, Topcu S, Perçin S. Simultaneous bilateral fractures of the femoral neck and superior pubis ramus following renal failure-induced hypocalcaemic convulsions. Br J Clin Pract. 1990 Dec;44(12):774-6.

15. Kapukaya A, Aslan H, Necmioglu S, Kandiya E. Kronik böbrek yetmezligi zemininde bilateral spontan femur boynu kırıg1: vaka takdimi. Journal of Turgut Ozal Medical Center 1997;4(2):197-9.

16. Ogun TC, Memik R, Yel M, Sarlak A. Bilateral pathologic femoral neck fracture as a consequence of renal osteodystrophy: Report of two cases and review of the literature. J Arthroplasty Arthroscopy Surg 2001;12(2):199-202.

17. Hung KH, Lee CT, Gau YL, Chen JB. Neglected bilateral femoral neck fractures in a patient with endstage renal disease before chronic dialysis. Ren Fail. 2001 Nov;23(6):827-31.

18. Karapinar H, Ozdemir M, Akyol S, Ulkü O. Spontaneous bilateral femoral neck fractures in a young adult with chronic renal failure. Acta Orthop Belg. 2003;69(1):82-5.

19. Devkota P, Ahmad S. Bilateral impacted femoral neck fracture in a renal disease patient. Niger Med J. 2013 Sep;54(5):354-5. doi: 10.4103/0300-1652.122374.

20. Garcia FL, Dalio RB, Sugo AT, Picado CHF. Bilateral spontaneous fracturing of the femoral neck in a patient with renal osteodystrophy. Rev Bras Ortop. 2014;49(5):540-2.

21. Sathyanarayana V, Patel MT, Raghavan S, Naresh D. Simultaneous Bilateral Femur Neck Fracture in A Young Adult with Chronic Renal Failure- A Case Report and Review of Literature. J Orthop Case Rep. 2015 OctDec;5(4):24-6. doi: 10.13107/jocr.2250-0685.337.

22. Sarıkaya B, Kültür T. Nadir görülen iki taraflı kalça agrısı nedeni: bilateral spontan proksimal femur kırıg1. Kahramanmaras Sütçü imam Üniversitesi Tıp Fakültesi
Dergisi (KSÜ T1p Fak Der) 2015;10(1):11-13.

23. John R, Kumar P, Aggarwal S, Rajnish RK, Agarwal S, Vatsyan K. Simultaneous, Non-traumatic, BilateralNeck Femur Fractures in Uremic Renal Osteodystrophy: A Report of Three Cases and Literature Review. J Orthop Case Rep. 2018 Mar-Apr;8(2):90-4. doi: 10.13107/ jocr.2250-0685.1066.

24. Gerakis A, Hadjidakis D, Kokkinakis E, Apostolou T, Raptis S, Billis A. Correlation of bone mineral density with the histological findings of renal osteodystrophy in patients on hemodialysis. J Nephrol. 2000 NovDec;13(6):437-43.

25. Jamal SA, Hayden JA, Beyene J. Low bone mineral density and fractures in long-term hemodialysis patients: a meta-analysis. Am J Kidney Dis. 2007 May;49(5):67481.

26. Prasad B, Ferguson T, Tangri N, Ng CY, Nickolas TL. Association of Bone Mineral Density With Fractures Across the Spectrum of Chronic Kidney Disease: The Regina CKD-MBD Study. Can J Kidney Health Dis. 2019 Aug 20;6:2054358119870539. doi: $10.1177 / 2054358119870539$.

27. Jamal SA, Swan VJ, Brown JP, Hanley DA, Prior JC, Papaioannou A, Langsetmo L, Josse RG; Canadian Multicentre Osteoporosis Study Research Group. Kidney function and rate of bone loss at the hip and spine: the Canadian Multicentre Osteoporosis Study. Am J Kidney Dis. 2010 Feb;55(2):291-9. doi: 10.1053/j. ajkd.2009.10.049.

28. Ramanath SK, Shah RH, Pradyumna YK. Ayurvedic Medications as Accelerating Cause of Atraumatic Bilateral Femur Neck Fracturein a Young Indian Male with Kidney Disease: A Unique Case Report. J Orthop Case Rep. 2019 Jan-Feb;9(1):45-8. doi: 10.13107/ jocr.2250-0685.1302.

29. Mittalhenkle A, Gillen DL, Stehman-Breen CO. Increased risk of mortality associated with hip fracture in the dialysis population. Am J Kidney Dis. 2004 Oct;44(4):672-9.

30. Kaneko TM, Foley RN, Gilbertson DT, Collins AJ. Clinical epidemiology of long-bone fractures in patients receiving hemodialysis. Clin Orthop Relat Res. 2007 Apr;457:188-93.

31. Park JC, Kovesdy CP, Duong U, Streja E, Rambod M, Nissenson AR, Sprague SM, Kalantar-Zadeh $\mathrm{K}$. Association of serum alkaline phosphatase and bone mineral density in maintenance hemodialysis patients. Hemodial Int. 2010 Apr;14(2):182-92. doi: 10.1111/j.1542-4758.2009.00430.x.

32. Maruyama Y, Taniguchi M, Kazama JJ, Yokoyama K, Hosoya T, Yokoo T, Shigematsu T, Iseki K, Tsubakihara Y. A higher serum alkaline phosphatase is associated with the incidence of hip fracture and mortality among patients receiving hemodialysis in Japan. Nephrol Dial Transplant. 2014 Aug;29(8):1532-8. doi: 10.1093/ndt/ gfu055. 